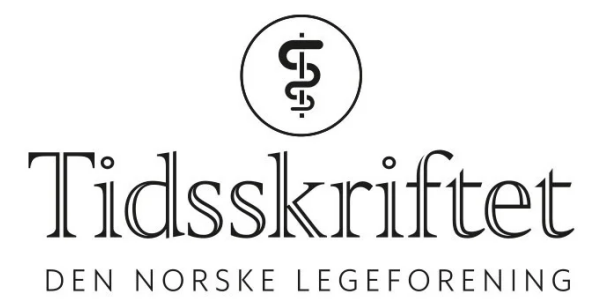

\title{
Operasjoner uten arr
}

KRONIKK

ESTHER KUHRY

Email: esther.kuhry@gmail.com

GJERMUND JOHNSEN

\section{RONALD MÅRVIK}

Nasjonalt senter for avansert laparoskopisk kirurgi

St. Olavs hospital

7006 Trondheim

\section{ROBIN GAUPSET}

Kirurgisk avdeling

Sykehuset Namsos

Helse Nord-Trøndelag

7800 Namsos

Ved transluminal endoskopisk kirurgi, eller NOTES (Natural Orifice Transluminal Endoscopic Surgery), bruker man naturlige kroppsåpninger som munn, vagina, urethra og anus som tilgang. Teknikken kan derfor omtales som kroppsåpningsbasert transluminal kirurgi. Ved denne type kirurgi uten hudincisjoner, unngår man arr, arrbrokk og sårinfeksjoner. Metoden bygger på minimalt invasive kirurgiske teknikker og endoskopi med fleksibelt skop. Den er lovende, men bør på det nåværende tidspunkt kun anvendes på pasienter innenfor godkjente kliniske studier. 


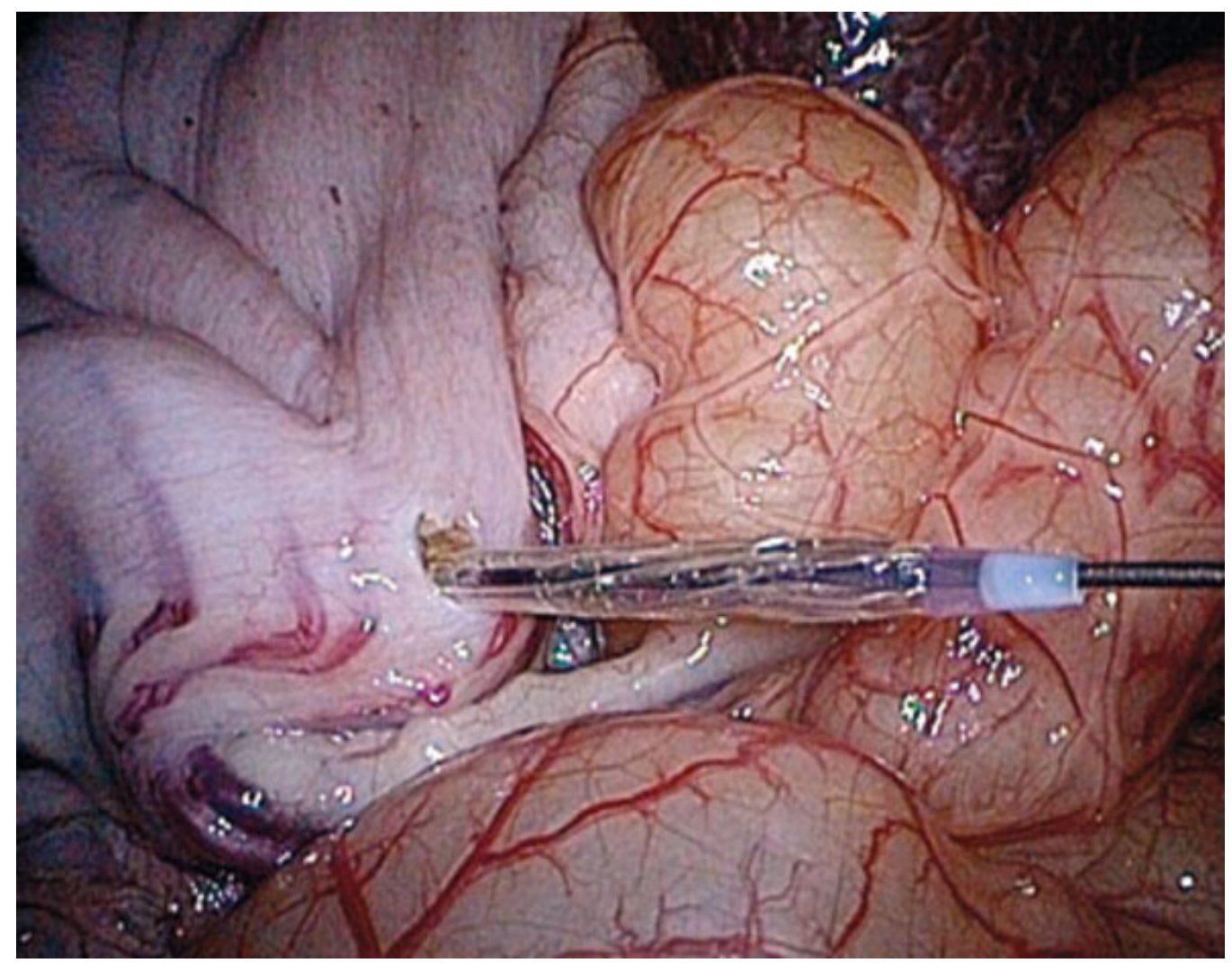

Hullet i magesekken blokkes opp til samme dimensjon som gastroskopet. Skopet introduseres deretter i bukhulen. Operasjon på gris

De siste 20 årene har laparoskopi erobret en stor plass innenfor det kirurgiske faget. Ved laparoskopi eller kikkhullskirurgi opererer man med instrumenter som føres inn gjennom små snitt i bukveggen i stedet for å operere gjennom et større snitt (åpen kirurgi). Sammenliknet med åpen kirurgi innebærer laparoskopisk utførte inngrep mindre blodtap, mindre smerter, kortere rekonvalesens og bedre kosmetisk resultat. Laparoskopisk tilgang er blitt førstevalg ved bl.a. kolecystektomi, overvektskirurgi og fundoplikasjon ved gastroøsofageal reflukssykdom.

Det utvikles nå en kirurgisk teknikk som er enda mindre invasiv. Den internasjonale betegnelsen på denne nye teknikken er NOTES (Natural Orifice Transluminal Endoscopic Surgery). Ved metoden bruker man naturlige kroppsåpninger som tilgang, den kan derfor omtales som kroppsåpningsbasert transluminal kirurgi. Gjennom et snitt i magesekken (transgastrisk), vagina (transvaginalt), colon (transkolonisk), rectum (transrektalt) eller blæren (transvesikalt) fører man spesielt utviklede instrumenter ut i bukhulen og utfører inngrep her, for eksempel kolecystektomi eller appendektomi. Teoretisk kunne dette ha fordeler for pasienten som for eksempel mindre smerter og ingen risiko for arrbrokk. Bedret kosmetisk resultat og fravær av sårinfeksjoner er andre momenter. I tillegg åpner denne metoden for muligheten til å utføre noen av inngrepene utenfor operasjonsstuen, for eksempel på intensivavdelingen (1).

Selv om teknikken fortsatt må anses som eksperimentell og stort sett brukes i dyreforsøk, holdes det allerede kurs og kongresser om den over hele verden. Tilhengerne av metoden mener at den vil forandre det kirurgiske faget, slik som introduksjonen av laparoskopisk kirurgi gjorde det i 1990-årene. Kritikerne tror at slik kirurgi er for komplisert og for dyrt og er uten signifikante fordeler sammenliknet med laparoskopisk teknikk.

\section{Kunnskapsbasert medisin?}

De første publikasjonene om metoden omhandlet teknikk som kan brukes til å suturere eller lage anastomoser via et fleksibelt endoskop. Metodene ble utprøvd i dyreforsøk (2 2 ). Den første publikasjonen som beskriver et inngrep utført på et levende dyr gjennom 
naturlige kroppsåpninger ble publisert for bare fem år siden, da Kalloo og medarbeidere rapporterte om en diagnostisk laparoskopi utført gjennom magesekken på en gris (3). Senere har andre rapportert om vellykkede transgastriske inngrep på gris, som for eksempel kolecystektomi, gastrojejunostomi, oovorektomi, sterilisering og splenektomi. Diagnostiske laparoskopier og torakoskopier på gris har også vært utført gjennom blæren $(4,5)$. Mediastinoskopi er blitt forsøkt på gris gjennom oesophagus ( $\underline{6})$. Diagnostisk laparoskopi og kolecystektomi gjennom tykktarmen har også vist seg å være mulig i dyremodell (7.).

Bruk av naturlige kroppsåpninger ved kirurgiske inngrep hos mennesker er foreløpig svært begrenset. Et unntak er den transvaginale tilgangen, som har vært brukt ved gynekologiske operasjoner i mange år. Slik tilgang er nå også blitt brukt i transluminal endoskopisk kirurgi. I april 2007 utførte man i Strasbourg verdens første transvaginale kolecystektomi på en pasient ved hjelp av et fleksibelt endoskop (요). Operasjonen forløp ukomplisert. Nylig er de første serier om transvaginal kolecystektomi hos pasienter blitt publisert (9) og også transvaginal gastrektomi med langsgående ventrikkelreseksjon

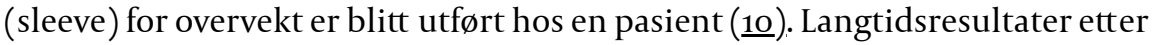
transvaginale inngrep, som for eksempel risiko for utvikling av dyspareuni, er ikke kjent.

Utilsiktet perforasjon av magesekken, for eksempel ved endoskopisk mucosareseksjon av tidlig ventrikkelcancer er blitt behandlet ved å sette klips endoskopisk i stedet for å utføre laparoskopisk eller åpen sutur av perforasjonen (11). Hazey og medarbeidere viste i 2007 $i$ en pilotstudie at transgastrisk diagnostisk peritoneoskopi hos pasienter med svulster i pancreas trygt kan utføres (므). På lik har man utført transrektale sigmoidektomier (13).

Det er nå forskjellige humane studier av transluminal endoskopisk kirurgi på gang. Det utføres bl.a. appendektomier, leverbiopsier, gastroenterostomier og sterilisering via kroppsåpningskirurgi. Publikasjoner om slike inngrep forventes i løpet av kort tid.

\section{Samarbeid med gastroenterolog nødvendig}

I de fleste europeiske land utføres diagnostisk og terapeutisk endoskopi, som for eksempel gastroskopi og koloskopi, av gastroenterologer. Kirurger vil derfor ofte trenge samarbeid med gastroenterologer for å kunne gjennomføre transluminale endoskopiske inngrep. Gastroenterologen må føre skopet, mens kirurgen opererer. Transvesikale eller transvaginale operasjoner utføres ofte i samarbeid med urologer eller gynekologer. Dette medfører at man må jobbe på tvers av grenspesialitetene, noe som kan medføre en del praktiske problemer. I Norge er mange generelle kirurger og spesialister i gastroenterologisk kirurgi erfarne endoskopører. Forholdene i Norge og de øvrige nordiske land er derfor sannsynligvis godt tilrettelagt for forskning og videre utvikling av metoden.

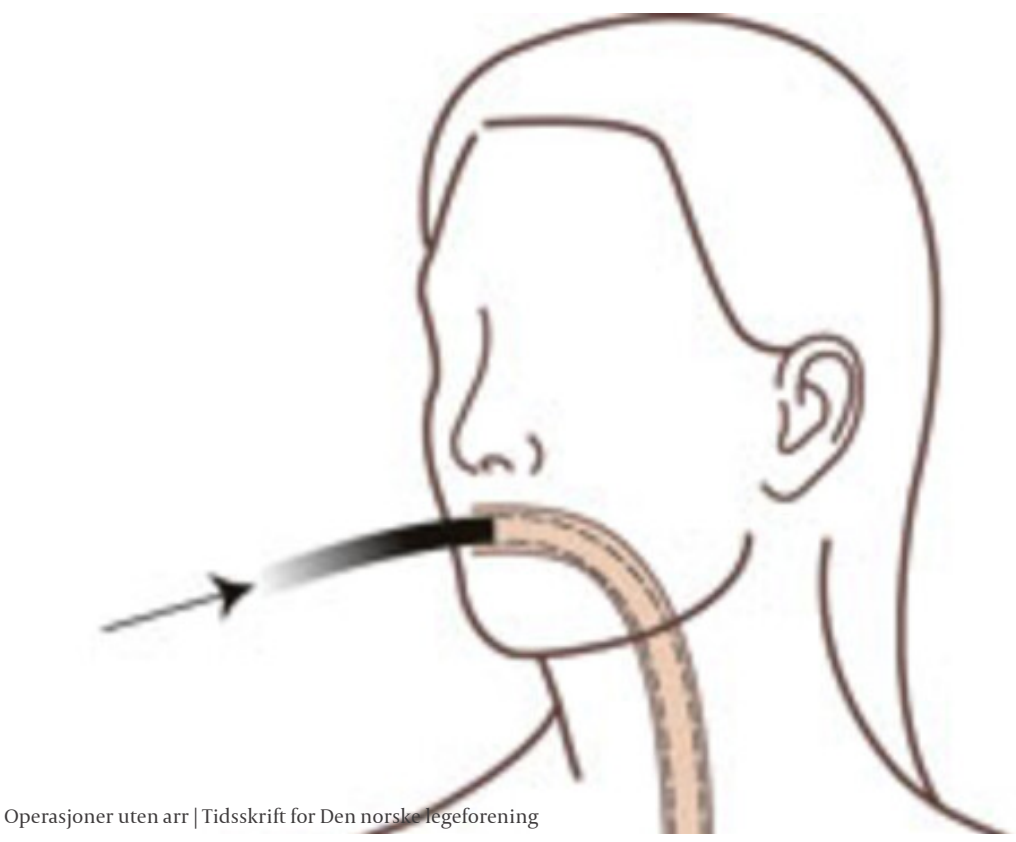




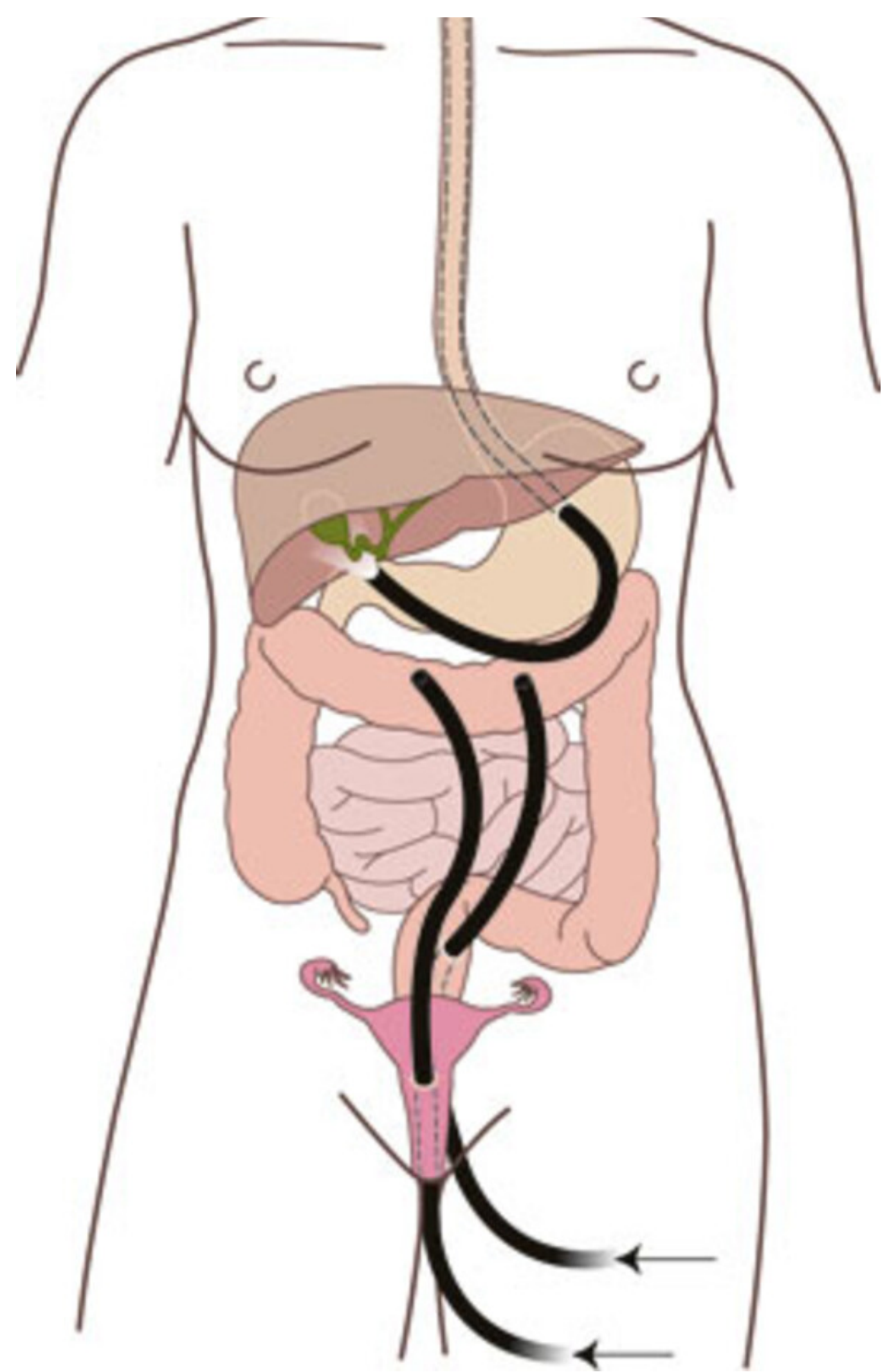

Forskjellige tilganger ved kroppsåpningsbasert transluminal kirurgi, flere kan kombineres

\section{Er denne teknikken fremtiden?}

Selv om de forløpige publikasjoner viser lovende resultater mht. teknisk gjennomførbarhet er mange fortsatt skeptiske til om bruk av kroppens naturlige åpninger vil bli fremtidens måte å operere på. Ideen om å lage hull i friske organer for tilgang til for eksempel bukhulen virker dramatisk fremfor å oppnå det samme via små åpninger i bukkveggen. Det er også flere problemer med teknikken som ennå ikke er løst. Spesielt ved 
transgastrisk, transkolonisk og transrektal tilgang har man problemer med steriliteten. I tillegg er det vanskelig å lukke hull i magesekken og colon, fordi det må gjøres med instrumenter som introduseres via et endoskop. Lekkasje kan potensielt medføre livstruende komplikasjoner. Det er derfor avgjørende for utviklingen av denne operasjonsmetoden at man klarer å utvikle instrumenter som gjør slike prosedyrer mulige på en trygg og reproduserbar måte.

Generelt vil den videre utviklingen i stor grad være avhengige av utvikling av utstyr som er egnet til å løse de tekniske utfordringer metoden innebærer. Dette gjelder både suturteknikk, instrumenter for å kunne utøve traksjon på organer og for å kunne behandle eventuelle komplikasjoner under inngrepet. Slik utvikling er allerede et stort satsingsområde hos de fleste større aktuelle utstyrsleverandørene. Fordi denne måten å utføre inngrep på er avansert og det trengs spesielt utstyr, forventes det at metoden er assosiert med høye kostnader og muligens en lang læringskurve.

Ingen humane studier der kirurgi via kroppens naturlige åpninger sammenliknes med andre operasjonsteknikker er publisert. Det trengs studier for å avklare om kroppsåpningsbasert transluminal kirurgi gir mindre smerter, mindre adheranser og kortere rekonvalesens enn laparoskopisk kirurgi. Det er viktig for den videre utviklingen å identifisere mulige områder hvor metoden kan ha fordeler. Et av områdene hvor teknikken kan være indisert, er hos pasienter på intensivavdelingene. Mange intensivpasienter dør på grunn av abdominale infeksjoner. CT gir ikke alltid tilstrekkelig informasjon for å kunne stille diagnose, og noen pasienter har økt risiko ved transport. Laparoskopi på intensivavdelingen har vært utført sporadisk, men anses ikke som en rutineprosedyre, på grunn av problemer med bl.a. steriliteten. Kroppsåpningsbasert transluminal kirurgi kan være et nytt diagnostisk verktøy som muliggjør bedret diagnostikk hos intensivpasienter (1) .

Utviklingen på området går raskt. Nesten ukentlig publiseres det artikler som bygger på dyrefors $\varnothing \mathrm{k}$ og som beskriver nye prosedyrer som utføres gjennom naturlige kroppsåpninger. Bortsett fra noen få artikler som beskriver pasientkasuistikker, finnes det ingen studier om metoden brukt på pasienter. Det vil sannsynligvis ta flere år før de første resultatene fra store kliniske studier vil være tilgjengelig.

På dette tidspunktet fraråder de store endoskopiske foreninger (ASGE, SAGES, ESGE, EAES) å utføre denne type operasjoner på pasienter annet enn i kliniske studier. I tillegg anbefales det at slike prosedyrer utføres av team med kompetanse i både avansert laparoskopi og terapeutisk endoskopi (14.), og at studiene registreres i et sentralt register som koordineres av de store foreningene (Euro-NOTES-registeret for Europeiske studier).

\section{Konklusjon}

Kroppsåpningsbasert transluminal kirurgi representerer en spennende utvikling innenfor det kirurgiske og gastromedisinske fagfeltet. For tiden finnes det ikke nok data for å kunne konkludere med at metoden har signifikante fordeler for pasientene. Flere dyrefors $ø \mathrm{k}$ og kliniske studier er nødvendig for både å utvikle og evaluere teknikken videre. Foreløpig bør metoden kun anvendes på pasienter innenfor godkjente, kliniske studier.

\section{Oppgitte interessekonflikter:}

Ingen 


\section{LITTERATUR}

1. Onders RP, McGee MF, Marks J et al. Natural orifice transluminal endoscopic surgery (NOTES) as a diagnostic tool in the intensive care unit. Surg Endosc 2007; 21: 681-3.

2. Fritscher-Ravens A, Mosse CA, Mills TN et al. A through-the-scope device for suturring and tissue approximation under EUS control. Gastrintest Endosc 2002; 56: 737-42.

3. Kalloo AN, Singh VK, Jaganath SB et al. Flexible transgastric periteneoscopy: a novel approach to diagnostic and therapeutic interventions in the peritoneal cavity. Gastrointest Endosc 2004; 60: 114-7.

4. Lima E, Rolanda C, Pego JM et al. Transvesical endoscopic peritoneoscopy: a novel $5 \mathrm{~mm}$ port for intra-abdominal scarless surgery. J Urol 2006; 176: 802-5.

5. Lima E, Henriques-Coelho T, Rolando C et al. Transvesical thoracoscopy: a natural orifice translumenal endoscopic approach for thoracic surgery. Surg Endosc 2007; 21: 854-8.

6. Sumiyama K, Gostout CJ, Rajan E et al. Transesophageal mediastinoscopy by submucosal endoscopy with mucosal flap safety valve technique. Gastrointest Endosc 2007; 65: 679-83.

7. Pai RD, Fong DG, Bundga ME et al. Transcolonic endoscopic cholecystectomy: a NOTES survival study in a porcine model. Gastrointest Endosc 2006; 64: 428-34.

8. Maresceaux J, Dallemagne B, Perretta S et al. Surgery without scars: report of transluminal cholecystectomy in a human being. Arch Surg 2007; 142: 823-6.

9. Forgione A, Maggioni D, Sansonna F et al. Transvaginal endoscopic cholecystectomy in human beings: preliminary results. J Laparoendosc Adv Surg Tech A 2008; 18:345-51.

10. Ramos AC, Zundel N, Neto MG et al. Human hybrid NOTES transvaginal sleeve gastrectomy: initial experience. Surg Obes Relat Dis 2008; 4: 660-3.

11. Minami S, Gotoda T, Ono H et al. Complete endoscopic closure of gastric perforation induced by endoscopic resection of early gastric cancer using endoclips can prevent surgery. Gastrointest Endosc 2006; 63: 596-601.

12. Hazey JW, Narula VK, Renton DB et al. Natural-orifice transgastric endoscopic periteneoscopy in humans: initial clinical trial. Surg Endosc 2007; 22: 16-20.

13. Whiteford MH, Denk PM, Swanstrom LL. Feasibility of radical sigmoid colectomy performed as natural orifice translumenal endoscopic surgery (NOTES) using transanal enoscopic microsurgery. Surg Endosc 2007; 21:1870-4.

14. ASGE/SAGES Working group on natural orifice translumenal endoscopic surgery. White Paper October 2005. Gastrointest Endosc 2006; 63: 199-203.

Publisert: 11. juni 2009. Tidsskr Nor Legeforen. DOI: 10.4045/tidsskr.08.0242

Manuskriptet ble mottatt 10.9. 2008 og godkjent 16.4. 2009. Medisinsk redaktør Michael Bretthauer. (C) Tidsskrift for Den norske legeforening 2023. Lastet ned fra tidsskriftet.no 26. april 2023. 